\title{
Zorgen voor morgen? The day after...
}

Citation for published version (APA):

van de Mheen, D. (2013). Zorgen voor morgen? The day after... Maastricht University. https://doi.org/10.26481/spe.20131115dm

Document status and date:

Published: 15/11/2013

DOI:

10.26481/spe.20131115dm

Document Version:

Publisher's PDF, also known as Version of record

\section{Please check the document version of this publication:}

- A submitted manuscript is the version of the article upon submission and before peer-review. There can be important differences between the submitted version and the official published version of record.

People interested in the research are advised to contact the author for the final version of the publication, or visit the DOI to the publisher's website.

- The final author version and the galley proof are versions of the publication after peer review.

- The final published version features the final layout of the paper including the volume, issue and page numbers.

Link to publication

\footnotetext{
General rights rights.

- You may freely distribute the URL identifying the publication in the public portal. please follow below link for the End User Agreement:

www.umlib.nl/taverne-license

Take down policy

If you believe that this document breaches copyright please contact us at:

repository@maastrichtuniversity.nl

providing details and we will investigate your claim.
}

Copyright and moral rights for the publications made accessible in the public portal are retained by the authors and/or other copyright owners and it is a condition of accessing publications that users recognise and abide by the legal requirements associated with these

- Users may download and print one copy of any publication from the public portal for the purpose of private study or research.

- You may not further distribute the material or use it for any profit-making activity or commercial gain

If the publication is distributed under the terms of Article $25 \mathrm{fa}$ of the Dutch Copyright Act, indicated by the "Taverne" license above, 
Prof. dr. Dike van de Mheen Faculty of Health Medicine and Life Sciences

\section{Zorgen voor morgen? The day after....}




\section{Zorgen voor morgen? The day after....}

Meneer de Prorector, meneer de decaan, dames en heren

Hebben wij zorgen voor morgen? Of kunnen wij zorgen voor morgen? De toekomst zal het leren.. Na vandaag, the day after, weet u meer. Deze rede gaat over middelengebruik en risicogedrag bij jongeren. Dan weet $u$ vast waar we heen gaan in het vervolg van dit verhaal.

Ik zal beginnen met wat nieuwsberichten en krantenkoppen. (1) Eerst over waar we ons zorgen over kunnen, mogen en ook moeten maken. Onze jongeren drinken veel en beginnen jong. Zorgwekkend is dat ze soms in coma in het ziekenhuis terecht komen. Alcohol en ook cannabis lijken schadelijk voor jonge hersenen en leiden tot diverse lichamelijke en psychische aandoeningen. Het adolescente brein is "nog niet af", en vatbaarder voor veranderingen dan het volwassen brein. De kans op verslaving neemt daarom toe als men op jonge leeftijd begint met middelengebruik (Smit, 2007). Daarnaast hebben alcohol- en drugsgebruik ernstige gevolgen voor de samenleving: schooluitval, agressie en geweld, en verkeersdoden. (o.a. Hammink et al, 2012). En er zijn nieuwe drugs in opkomst zoals GHB waar we op het gebied van behandeling en preventie nog onvoldoende voor zijn toegerust. (2) En als we het niet over gevolgen voor het individu hebben dan zorgt de overlast en criminaliteit die samenhangt met cannabisgebruik wel voor zorgen voor morgen. Het coffeeshopbeleid bezorgt ons heel wat hoofdbrekens. Daar hoef ik in Maastricht zeker niets over te vertellen. (3) Ook biedt het internet steeds meer verleidingen aan onze jongeren: online games, online pornografie en online gokken. (4) Onlangs verscheen een boek over zogenaamde sociobesitas: zijn we in de toekomst zelfs verslaafd aan sociale media?

Maar er zijn ook andere krantenkoppen. Wij kunnen zórgen voor morgen. Wij zijn op de goede weg. Wij hebben de tools in handen om erger te voorkomen en zelfs wellicht het tij te keren. (5) De Nederlandse jeugd is de afgelopen jaren minder gaan drinken, blowen en roken. Het aantal verkeersdoden door alcohol is gedaald, het aantal probleemgokkers is stabiel gebleven. (6) De minimumleeftijd voor de verkoop van alcohol gaat per 1 januari 2014 naar 18 jaar en ook de minimumleeftijd voor 
tabaksverkoop volgt en gaat naar 18. (7) Er is meer aandacht voor preventie, om een voorbeeld te noemen: meer dan 10.000 jongeren bezochten een website voor het omgaan met mogelijk problematisch gamen (Van Rooij \& Meerkerk, 2012). Is het glas half vol, of is het half leeg? Voor ik $u$ hier een wetenschappelijke verhandeling over ga geven heb ik op het centraal station van Maastricht een paar willekeurige reizigers hun mening hierover gevraagd. [8 filmpje].

U ziet: het kan alle kanten op. (9) Kent u het boekje "Omdenken"? (Gunster, 2010) Het leert ons om eens anders tegen de wereld aan te kijken en onze vaste kaders los te laten. "Omdenken" zegt: of het glas half vol is of half leeg is helemaal geen relevante vraag: het gaat erom: waar is de kraan? In deze rede neem ik u mee door onze mogelijkheden en kansen om het glas te vullen: wij hébben zorgen voor morgen maar kúnnen ook zorgen voor morgen. Met onze kennis, onze middelen en ons onderwijs hebben we genoeg in handen: een mooie toekomst ís mogelijk! $U$ wilt natuurlijk feiten en bewijs voor deze positieve benadering: "dat gaat zomaar niet”. En daar heeft u gelijk in. Ik zal u laten zien waar ik die positieve kijk op baseer.

Mijn rede spitst zich toe op jongeren. Ik moest keuzes maken in de 45 minuten die mij ter beschikking staan, en wie de jeugd heeft, heeft de toekomst. Daarmee wil ik echter niet zeggen dat ook andere leeftijdsgroepen in de samenleving geen aandacht behoeven. Dat is voor de volgende inaugurele rede. Hoewel de vraag in deze filmpjes zich toespitste op alcohol en drugsgebruik van de jongeren, zal ik het in mijn rede ook over ander risicogedrag van jongeren hebben.

Ik zal u eerst wat feiten en cijfers laten zien. Dan weten we waar we het over hebben. 


\section{Internet- en gameverslaving}

(10) Ik begin eens niet met alcohol en drugs, maar met internet- en game "verslaving'. Het IVO, waar ik werk in Rotterdam, voert het monitoronderzoek "Internet en jongeren" uit, in samenwerking met de Stichting Volksbond. Dit is een jaarlijks terugkerend onderzoek onder jongeren in het voortgezet onderwijs. Van deze jongeren is $1,5 \%$ - dat zijn in Nederland bijna 12.000 jongeren - "verslaafd" aan online internet games. (Van Rooij et al; 2011.). Slechts een deel van deze groep zal in aanmerking komen voor klinische behandeling, maar in 2012 werden toch zo'n 300 jongeren behandeld werden voor gameproblematiek (Wisselink, persoonlijke mededeling, 2013).

Gamen kost tijd: jongeren besteedden in 2012 zo'n 14 uur per week aan online gamen. De problematische gamers besteden nog meer tijd aan het gamen en zitten gemiddeld zo'n 37 uur per week te gamen, zeg maar een volle werkweek (Van Rooij et al, 2008). Verslaafde' online gamers hebben meer last hebben van sociale angst, depressiviteit en eenzaamheid en een hebben een negatiever zelfbeeld. Bovendien blijken vooral lager opgeleide en allochtone jongeren risico te lopen om verslaafd te raken.

(11) Naast het gamen zijn ook de sociale media populair. Bijna alle jongeren zijn actief met enige vorm van sociale media. Twitter is het meest populair: het percentage jonge gebruikers nam toe van $7 \%$ in 2010 naar $57 \%$ in $2012.6 \%$ van de jongeren geeft aan het gebruik van sociale media problematisch te vinden (Van Rooij en Schoenmakers, 2013).

De prevalentie, dat is het vóórkomen, van risicovol internetgebruik onder Nederlandse jongeren is gemiddeld in vergelijking met andere Europese landen. Ook ligt de prevalentie van jongeren die online gokken in Nederland dicht bij het Europese gemiddelde. Het percentage Nederlandse jongeren dat naar porno kijkt is iets lager, en ook scoort Nederland relatief laag op het gebied van online gepest worden. Nederlandse jongeren doen het in vergelijking met andere Europese landen dus relatief goed wat betreft het risicovolle internetgebruik.(Van Duin et al, 2013). 


\section{Alcohol- en drugsgebruik}

De Nationale Drug Monitor van het Trimbosinstituut (2013) geeft ons een prachtig overzicht van alle cijfers rond alcohol en drugsgebruik in Nederland. Vorige week is het jaarbericht 2012 verschenen. $U$ kunt alle cijfertjes daarin nalezen, dus ik ga alle details hier niet herhalen.

(12) Samenvattend zegt de Nationale Drug Monitor dat het drugsgebruik (zowel cannabis als harddrugs) onder Nederlandse scholieren ongeveer stabiel is in de afgelopen vijf jaar. Het cannabisgebruik ligt wel hoger dan het Europees gemiddelde. Het gebruik van GHB onder scholieren komt gelukkig relatief weinig voor. Tussen 2003 en 2011 is het alcoholgebruik afgenomen. Deze daling deed zich vooral voor in de jongste leeftijdsgroepen. Het percentage binge drinkers (dat is drinken van 5 of meer glazen bij één gelegenheid) is onder scholieren ook gedaald in deze periode. Het aantal jongeren dat met een alcohol intoxicatie in een ziekenhuis wordt behandeld steeg tussen 2007 en 2011, maar daalde licht naar 706 jongeren in 2012. Het percentage scholieren dat ooit heeft gerookt daalde van 2003 naar 2007 en stabiliseerde in 2011 op $36 \%$.

Cijfers van het Nationaal Prevalentie Onderzoek onder de algemene volwassen bevolking, die de door het IVO zijn geanalyseerd, laten in grote lijnen hetzelfde beeld zien (Van Rooij et al, 2011). Het alcoholgebruik van de jongeren van 16-24 (dat is dus een oudere groep jongeren dan de scholieren waar ik het net over had) is ook min of meer stabiel gebleven of iets gedaald. In 2009 is ruim $70 \%$ een actuele drinker. Ook hier is het bingedrinken afgenomen. Het percentage rokers is in deze leeftijdsgroep aanzienlijk afgenomen, en drugsgebruik lijkt min of meer gestabiliseerd.

\section{Gokken}

(13) Voor het legaal deelnemen aan kansspelen geldt de leeftijdsgrens van 18 jaar, hoewel er ook gemeenten in Nederland zijn die een grens van 21 jaar hanteren voor de toegang tot speelautomatenhallen en casino's. Het percentage risicospelers en probleemspelers onder jongeren bleef stabiel tussen 2005 en 2011 (rond de 0.5\%) en het percentage recreatieve gokkers daalde. 55\% van de jongeren onder de 25 heeft ooit aan een kansspel deelgenomen. (Bieleman, persoonlijke mededeling). 
Maar wanneer we ook poker als kansspel meenemen, zowel in een casino als online, komen we hoger uit. (Bieleman et al, 2011).

Online gokken is tot nu toe illegaal, maar per 1 januari 2015 wordt online gokken toegestaan. Deze ontwikkeling kan leiden tot een toename van online gokken, met name online pokeren. We weten niet of dat ook tot een toename in gokverslaving leidt. Het is zeker belangrijk dat te onderzoeken.

\section{Online porno}

Wij onderzochten ook mogelijk probleemgedrag met betrekking tot online-pornografie (Meerkerk et al, 2011). Onder jonge mannen van 18-24 jaar kijkt 25\% minstens 1-2 keer per week online porno. Ter vergelijking: bij vrouwen in deze leeftijdscategorie is dat $3 \%$. In hoeverre dit echt problematisch gedrag is, zullen we nog onderzoeken. Wellicht valt dat problematische wel mee gezien het volgende plaatje (14): in een onderzoek waarin voor de controlegroep mannen werden gezocht die geen porno kijken konden ze niemand vinden.

\section{Gebruik van de zorg}

De Stichting IVZ verzamelt alle cijfers van de verslavingszorg in Nederland. Jeroen Wisselink van het IVZ was zo aardig om voor mij de cijfers voor jongeren onder de 25 uit te draaien. In 2012 waren er ruim 8000 jongeren onder de 25 jaar in zorg. Ten opzichte van 2003 is dat een behoorlijke stijging: maar t.o.v. 2010 is het een daling. (http://mijnladis.sivz.nl/ladisnl.html). In dit plaatje (15) ziet u de primaire problematiek van jongeren door de jaren heen. $U$ ziet dat de meeste problematiek ligt bij cannabis, alcohol en cocaïne. Het aantal jongeren dat hulp zoekt bij alcoholproblematiek is gestegen en de laatste jaren gestabiliseerd, het aantal jongeren dat hulp zoekt bij cocaïneproblematiek is afgenomen, en de vraag naar hulp bij cannabisproblematiek is toegenomen. (16) Wanneer we de jongeren eens vergelijken met ouderen zien we dat bij jongeren veruit de grootste vraag ligt bij cannabis, terwijl dat bij 55 plussers voornamelijk alcohol betreft. 


\section{Kwetsbare jongeren}

Maar, zult u zeggen, al die cijfers over het vóórkomen van middelengebruik en risicogedrag die u net heeft laten zien, gaan voornamelijk over de "brave" jeugd. Scholieren en jongeren uit de algemene bevolking die keurig vragenlijsten invullen. Moeten we ons niet veel meer richten op de extra kwetsbare jongeren? Ja, dat klopt. En daarom zal ik daar nu op inzoomen. (17) Over specifieke kwetsbare groepen zijn minder cijfers voorhanden. Wat is er aan de hand met deze jongeren en waarom zijn ze kwetsbaar? Juist bij jongeren die al in de jeugdzorg of jeugdhulpverlening zitten is middelengebruik en risicogedrag een onderschat probleem (o.a. Fettes et al, 2013). Ze hebben extra aandacht nodig en vooral ook: ze moeten beter bereikt worden met onze zorg en preventie.

In de Stichting Resultaten Scoren wordt samengewerkt door bestuurders van verslavingszorginstellingen, professionals en wetenschappers. Het doel is binnen de verslavingszorg meer evidence based te werken, onder andere door de ontwikkeling van richtlijnen en protocollen. Ik ben al enkele jaren met veel plezier lid van de Stuurgroep Resultaten Scoren. Het project "van kwetsbaar naar weerbaar" van Resultaten Scoren heeft als doel de kwaliteit en effectiviteit van preventie, behandeling en zorg voor kwetsbare jongeren op een hoger plan brengen. Dat gebeurt door het in kaart brengen van wetenschappelijke kennis, werkzame interventies en het opstellen van adviezen. Daarnaast door het ontwikkelen van interventies en het verspreiden van die kennis, onder andere. door onderwijsmodules te ontwikkelen.

De kwetsbare jeugd kenmerkt zich door een opeenstapeling van problemen (Snoek et al, 2010). Bij deze doelgroep zien we enerzijds een clustering van risicofactoren en anderzijds een clustering van problemen als gevolg van risicogedrag. Onderzoek toont aan dat bij het hebben van vier risicokenmerken, de kans op stoornissen vertienvoudigt. (Hermanns, 2009; Rutter, 2008). Voorbeelden van risicokenmerken zijn delinquentie, gedragsproblemen of opgroeien in een armoede situatie. Een achterliggende verklaring voor deze cumulatie is dat teveel stressoren leiden tot een ontregeling van de zelfregulatie van het hele gezin (Evans, 2003; Evans \& English, 2002; Hermanns, 2009). Daarbij hebben gezinnen in een maatschappelijke achterstandsituatie vaker met risicocumulatie te maken dan doorsneegezinnen. 
We moeten de hulp aan en preventie voor deze jongeren aanvliegen vanuit een ontwikkelingsperspectief: vroeg ingrijpen betekent dat gezin en school belangrijke domeinen worden voor preventie. Ondersteuning bij opvoeding is belangrijk, vóórdat al ernstig probleemgedrag is ontstaan.

\section{Preventie}

Ik heb u net laten zien dat we de zorg en preventie voor kwetsbare jongeren vroeg moeten inzetten. In het vervolg van dit betoog zal ik verder focussen op preventie. Wat verstaan we onder preventie? Op deze dia (18) ziet u dat uitgelegd: we onderscheiden universele preventie, selectieve preventie en geïndiceerde preventie. Universele preventie richt zich op algemene bevolking of een deelpopulatie die niet geïdentificeerd is op basis van een individuele risicofactor. Selectieve preventie richt zich op een subgroep van de populatie waarbij het risico op het ontwikkelen van in dit geval een verslavingsprobleem aanzienlijk groter is dan gemiddeld (bijvoorbeeld bij jongeren met lage sociaal economische status, of bij jongeren die opgroeien in probleemgezinnen). Geïndiceerde preventie richt zich op individuen die niet voldoen aan de diagnostische criteria voor een psychische of verslavingsstoornis, maar die wel reeds beperkte symptomen of aanleg hebben die voorafgaan aan de stoornis. Waar bij selectieve preventie nog geen problemen aanwezig hoeven te zijn, is dat bij geïndiceerde preventie wel het geval. (Cuijpers e.a., 2009).

Wat voor preventieve maatregelen hebben we zoal in de aanbieding? In grote lijnen hebben we twee categorieën: beleidsmaatregelen en preventieve interventies. (van Hasselt (red), 2010). (19)

Bij beleidsmaatregelen moet u denken aan (20): maatregelen rondom beschikbaarheid, prijsmaatregelen, leeftijdsgrenzen, verkeersmaatregelen, maatregelen gericht op de marketing door de alcoholindustrie en maatregelen gericht op handhaving. Veel van deze maatregelen zijn onderzocht en lijken effectief. Het voert hier te ver om ze één voor één te behandelen. Als voorbeeld noem ik het onderzoek van Karen Schelleman-Offermans die in 2012 bij Ronald Knibbe en mij promoveerde. Uit haar onderzoek blijkt dat in gemeenten die boetes opleggen bij het overtreden van de leeftijdsgrenzen, dronkenschap onder adolescenten minder voorkomt (Schelleman-Offermans, 2012). Of het verhogen van de verkoopleeftijd van alcohol en tabak in Nederland per 1 januari as. effect heeft op het gebruik, zullen we 
natuurlijk nog moeten onderzoeken. Uit onderzoek onder leiding van onder andere Ronald Knibbe blijkt dat het instellen van de minimumleeftijd voor de verkoop van tabak in 2003, leidde tot een verlaging van de tabaksverkoop aan adolescenten, en daarmee waarschijnlijk ook aan het verlagen van de rookprevalentie onder jongeren. (Verdonck et al, 2008).

(21) Preventieve interventies zijn bijv. massamediale campagnes, schoolinterventies, multicomponenten-interventies, interventies in de drinkomgeving, interventies via gezondheidszorg en welzijnswerk en online zelfhulp. Van deze interventies is deels wel en deels geen effectiviteit aangetoond, maar vaak is het nog niet onderzocht (van Hasselt (red), 2010). Dit jaar maakten Suzan Oudejans en Masha Spits een overzicht van beschikbare interventies voor verslavingspreventie, gericht op de jeugd. (Oudejans en Spits, 2013). Zij inventariseerden er maar liefst 243. Daarvan zijn verreweg de meesten echter niet op effectiviteit onderzocht: er waren er 24 (dat is $10 \%$ ) die een erkenning hadden van het Centrum voor Gezond Leven als goed beschreven, theoretisch goed onderbouwd of "waarschijnlijk effectief". Geen enkele was bewezen effectief.

Van sommige interventies is wel een effect aangetoond op kénnis, bewustwording en attitude, bijvoorbeeld bij massamediale campagnes, maar geen direct effect op gedrag (Cuijpers et al, 2009). Wel effectief lijken interventies die zich zowel op jongeren op school als op de ouders richten (Maat et al, 2010).

Preventieve interventies via de zorg zijn nog weinig onderzocht. Mijn collega Latifa Abidi is hier in Maastricht bij mij bezig met een promotieonderzoek op dit gebied in de huisartspraktijk. Resultaten hebben we daar echter nog niet van. Een ander promotieonderzoek naar de effectiviteit van een preventieve interventie wordt uitgevoerd wordt door collega Hans Dupont van Mondriaan. Deze kortdurende interventie, Moti-4 genaamd, is gericht op het terugdringen van problematisch cannabisgebruik bij jongeren. De interventie is gebaseerd op motiverende gespreksvoering. Op basis van voorlopige analyses lijkt de interventie een positief effect te hebben.

(22) Ook ons coffeeshopbeleid was ooit bedoeld als preventieve maatregel. In 2009 verscheen een omvangrijk boekwerk getiteld "de Evaluatie van het Nederlands drugsbeleid". Een van de meest bediscussieerde maatregelen is het beleid rondom coffeeshops. Hiermee wordt een scheiding van de cannabis- en harddrugsmarkt 
beoogd, met als doel het verkleinen van de kans dat cannabisgebruikers harddrugs gaan gebruiken. Het rapport concludeert dat de drugsmarkten in Nederland in vrij grote mate gescheiden zijn, én dat het hard drugs gebruik in Nederland laag is. Het is echter lastig om vast te stellen of die scheiding der markten nu efféct heeft gehad op het gebruik van hard drugs (Van Laar \& Van Ooyen-Houben (red), 2009). Het Nederlands drugsbeleid steunt op twee pijlers. Die van de bescherming van de volksgezondheid en van de bestrijding van overlast en criminaliteit (Beleidsnotitie drugsbeleid 2011 T.K. 24077-259). Dit volksgezondheidsdoel wordt nader omschreven als "het voorkómen dat in het bijzonder jeugdige burgers overgaan tot het gebruiken van drugs en aan de problematische gebruikers een medisch en/of sociaal hulpaanbod doen ter leniging van hun nood" (Drugsnota, 1995). De politieke en maatschappelijke discussie rondom het coffeeschopbeleid lijkt echter niet meer te gaan over het beschermen van het individu, maar voornamelijk over openbare orde en overlast. Het is jammer dat daarmee de aandacht voor de risico's van het individu naar de achtergrond verdwijnt.

\section{Richtlijnen en Protocollen}

De inzet op preventie uit zich ook in het ontwikkelen van richtlijnen en protocollen. (23) Zo hebben wij de richtlijn Vroegsignalering middelenmisbruik of -afhankelijkheid bij jongeren ontwikkeld (Snoek et al, 2010). Het doel van vroegsignalering is om problemen met middelengebruik zo vroeg mogelijk op te sporen en in te grijpen. We beschrijven in deze richtlijn hoe vroegsignalering van risicovol middelengebruik in z'n werk gaat. De richtlijn geeft adviezen over te gebruiken screeningsinstrumenten, over risicogroepen die aandacht behoeven, en geeft handvatten voor het opzetten van een ketensamenwerking. (24) Om een voorbeeld te geven: risicogroepen die aandacht behoeven volgens de richtlijn zijn onder andere delinquente jongeren, jongeren uit de institutionele zorg, school drop-outs en spijbelaars en jongeren met een licht verstandelijke beperking. Daarnaast gaat het om jongeren die opgroeien in ongunstige omstandigheden zoals een lage sociaal-economische status, ouders die middelen gebruiken of dak- en thuisloosheid. 


\section{Samenwerking}

Om effectieve preventie en behandeling voor jongeren op te kunnen zetten is samenwerking in de ketens van jeugdzorg, opvoeding en onderwijs, veiligheidshuizen, jeugd-ggz, jeugdgezondheidszorg en jeugdverslavingszorg essentieel. Daar zijn al hele mooie initiatieven voor in gang gezet. Wij keken naar de succesfactoren van samenwerkingsprojecten rond preventie en behandeling van jongeren met middelenproblematiek (Couwenbergh \& Wits, 2013) (25) .

Succesfactoren waren: het onderhouden van relaties; korte lijnen; ruimte, tijd en middelen om te pionieren en te vernieuwen, en inbedding in de eigen organisaties en in de bredere keten. Een mooi voorbeeld van samenwerking in preventie is bijv. het aanvalsplan drugs en alcohol op ROC's in Rotterdam. Hierin wordt door de gemeente, GGD, GGZ-verslavingszorg, politie en ROC's samengewerkt om het alcohol- en drugsgebruik bij MBO scholieren te verminderen (Gemeente Rotterdam, 2010). Een ander voorbeeld is het project wijkgerichte verslavingspreventie, dat onder andere. wordt uitgevoerd in de regio Zuid Limburg. Het doel is het verbeteren van het bereik van verslavingspreventie gericht op kwetsbare jongeren, door samenwerking te zoeken in de wijk. Deze werkwijze is gebaseerd op de RARmethodiek: Rapid Assessment en Response (Braam et al, 2004) (26). Hierbij wordt door middel van een aantal methoden informatie verzameld, die leidt tot de respons. Dat is in dit geval een aantal preventieactiviteiten in de wijk, zoals preventie gericht op ouders, het organiseren van sportactiviteiten en het inzetten van een outreachende preventiemedewerker. De effectiviteit van samenwerkingsverbanden is vaak nog niet onderzocht. Op dit moment voeren wij samen met de GGD en de ROC's in Rotterdam een studie uit naar de effectiviteit van het hiervoor genoemde aanvalsplan. Als het werkt kan zo'n aanpak landelijk ingevoerd worden. Volgend jaar hebben we de uitkomsten. Bij het project wijkgerichte verslavingspreventie onderzoeken we de meerwaarde van deze werkwijze voor het bereik van kwetsbare groepen. Ook daarvan verwachten we de resultaten in 2014. 


\section{Preventie is effectief}

Dat preventie loont heeft Johan Mackenbach met zijn collega's van de afdeling Maatschappelijke Gezondheidszorg van het ErasmusMC in Rotterdam overtuigend aangetoond. Bij dit instituut ligt een groot deel van mijn wetenschappelijk vorming. In zijn boek "Successen van preventie 1970-2010" (Mackenbach (red), 2011) (27) selecteerden hij in die periode de grootste successen in preventie waarmee jaarlijks duizenden doden en zieken worden voorkomen. Het grootste succes is de bestrijding van roken. Dankzij allerlei preventiemaatregelen zijn we minder gaan roken en dat scheelt jaarlijks ruim 6.900 sterfgevallen en meer dan 18.000 ernstig zieken. Andere successen op het gebied van jongeren zijn de preventie van tandbederf en vaccinaties tegen kinderziekten. En zo komt hij tot 22 succesvoorbeelden. Het succes van preventie hangt af van het samenspel tussen individuen, overheid en bedrijfsleven. Weer die samenwerking dus. Ook het bedrijfsleven kan een bijdrage leveren aan onze missie. Er zijn de laatste jaren vele initiatieven in de zogenaamde PPP's: privaat publieke partnerships. Als voorbeeld van inzet van het bedrijfsleven laat ik hier de vijf regels voor duurzaam leven zien, die Unilever publiceerde (Unilever, 2011) (28): maak het begrijpelijk voor de consument, maak het gemakkelijk, maak het begerenswaardig, maak het lonend en maak er een gewoonte van.

Enkele weken geleden stemde de ministerraad in met het Nationaal Preventie Programma van Minister Schippers en Staatssecretaris van Rijn (Rijksoverheid, 2013). In dit programma is onder andere aandacht voor leefstijl. De bewindslieden willen met het programma roken, overgewicht en overmatig alcoholgebruik tegengaan. So far, so good, kunnen we zeggen. Maar of het programma succesvol is hangt af van twee zaken: de uitvoering en het geld (29). Wat betreft de uitvoering komen in februari alle betrokkenen bij elkaar om het plan uit te werken en in de praktijk te brengen. Daar zijn we zelf bij, dus daar kunnen we een succes van maken. Het geld is een lastiger punt: als we zien wat er aan preventie wordt uitgegeven op het totaal van kosten van de gezondheidszorg is dat een relatief heel klein bedrag. Op dit moment wordt zo'n 87 miljard euro, dat is ca. 12\% van ons Bruto Nationaal Product, besteed aan de gezondheidszorg (CPB, 2013 in FD, 2013). Daarvan wordt nog geen 5\% uitgegeven aan preventie (Financieel dagblad, 06-04-2013). En, terwijl 
de uitgaven aan gezondheidszorg de laatste jaren sterk zijn gestegen, zijn die voor preventie licht gedaald (Mackenbach (red), 2011).

Ook voor het Nationaal Preventie Programma zijn slechts beperkt middelen beschikbaar. Maar zeker bij preventie gaat de kost voor de baat uit. Preventie loont: in gezondheid, maar ook in geld. In harde euro's is dat moeilijk te berekenen en zijn de rekenaars het ook niet met elkaar eens. Het RIVM (Van den Berg et al, 2013) zegt dat preventie waarschijnlijk niet direct tot lagere zórgkosten zal leiden. Belangrijk is echter dat preventie naast beperking van de zorgkosten andere maatschappelijke baten kent, zoals bij jongeren de verhoging van schoolprestaties. Price Waterhouse Coopers berekende in euro's wat preventie oplevert. Volgens hun berekening levert iedere euro die geïnvesteerd wordt in preventie van roken, overmatig alcoholgebruik en obesitas een substantieel rendement op voor de samenleving. Bij preventie van overmatig alcoholgebruik berekenen zij in verschillende scenario's een rendement van tussen de 60 en 280 procent. Daarbij becijferen ze dat preventie gericht op jongeren het meeste rendement oplevert (PWC, 2010). In de NPHF, federatie voor gezondheid, zijn alle relevante actoren op het gebied van de public health verenigd. De NPHF is een belangrijke gesprekspartner voor de overheid op het gebied van volksgezondheid. Zij betoogt dat de zorg zich moet bewegen van nazorg naar voorzorg, en dat de winst zit in een vitalere bevolking, innovatie, creativiteit en nieuwe werkwijzen (NPHF, 2012). Als voormalig bestuurslid van de NPHF schaar ik me graag achter dit standpunt.

\section{Preventie op de kaart}

In het voorafgaande heb ik u laten zien dat we veel interventies in handen hebben op het gebied van preventie. Maar veel is dus nog niet bewezen. We moeten daar nog veel onderzoek naar doen. Daar moeten we echter niet altijd op wachten. Zeker t.a.v. jongeren moeten we naar mijn mening het zogenaamde voorzorgprincipe hanteren dat zegt dat als er ernstige en onomkeerbare schade dreigt te ontstaan, een gebrek aan wetenschappelijk bewijs niet mag worden gebruikt als reden om maatregelen uit te stellen. Dit natuurlijk wel onder de voorwaarde dat redelijkerwijs het adagium "baadt het niet dan schaadt het niet" van toepassing is. Voorbeelden van maatregelen die op dit voorzorgsprincipe gebaseerd zijn, zijn het verhogen van de verkoopleeftijd van alcohol van 16 naar 18 jaar, en het voorstel tot plaatsen van cannabis met een thc gehalte hoger dan $15 \%$ op lijst I van de Opiumwet. 
(Expertcommissie Lijstenproblematiek Opiumwet, 2011). In beide gevallen lijken er immers genoeg aanwijzingen te zijn voor schadelijkheid voor de gezondheid, al is het wetenschappelijke bewijs nog niet ónomstotelijk vastgesteld.

Preventie is dus een goede keuze. Maar hoe krijgen we preventie op de agenda? De KNAW, de Koninklijke Nederlandse Academie van Wetenschappen maakt zich in een advies van mei dit jaar zorgen om de verwevenheid van wetenschap en overheid: wetenschap moet niet worden misbruikt om alleen het eigen gelijk te krijgen. Daarom vindt zij dat de overheid door richtlijnen over de omgang met wetenschappelijk onderzoek minder kans moet krijgen om wetenschappelijk advies naar eigen hand te zetten. "Wij zijn daar geen voorstander van" antwoorden minister Bussemakers en staatssecretaris Dekker (30). Ik vind dat we ons niet uit het veld moeten laten slaan door een dergelijke reactie. De aanhouder wint. De boodschap dat preventie loont moeten we als wetenschappers blijven uitzenden. Door krachten te bundelen, en goed onderzoek te blijven doen en te blijven rapporteren boeken we uiteindelijk resultaten. Omdat preventie nooit een acuut item is, is de strategie ook een "slow lobby". Preventie redt vele mensen en verhoogt hun kwaliteit van leven, maar die mensen zijn meestal niet aanwijsbaar: je weet nooit of jij het bent die wellicht anders was overleden aan de gevolgen van een ziekte of veel minder gezond was geweest. Een grote maatschappelijk lobby voor een preventiemaatregel zullen we dus niet snel krijgen. Het is de tijd rijp maken en wachten op het juiste moment. In 2008 hield ik mijn oratie aan de Erasmus Universiteit. Ik betoogde toen dat de verkoopleeftijd van alcohol naar 18 jaar verhoogd zou moeten worden, en dat de tijd daar zo onderhand rijp voor was. Mijn voorspelling is uitgekomen: vijf jaar later is het zover, met de verkoopleeftijd van tabak erbij. "Ceterum censeo Carthaginem delendam esse", of te wel "Overigens ben ik van mening dat Carthago verwoest moet worden" zei de Romeinse senator Cato bij elke redevoering. Wikipedia zegt hierover: "De strekking van deze uitspraak is dat dingen die belangrijk zijn voortdurend herhaald moeten worden. Wie, bijvoorbeeld in de publieke zaak, iets wil bereiken zal te pas en te onpas zijn boodschap moeten herhalen". Cato kreeg het voor elkaar: Carthago werd in 146 voor Christus door Rome verwoest.(31)

Niet alleen de zorg, maar ook het onderzoek, of zo $u$ wilt de wetenschap, ontwikkelt zich van aanbod gestuurd naar vraag gestuurd. Ik vind dat een goede zaak. 
Waarmee ik natuurlijk niet wil zeggen dat we geen fundamenteel onderzoek moeten doen: dat is zeker ook nodig om die preventieve interventies theoretisch te kunnen onderbouwen.

Met behulp van de wetenshap kunnen we maatschappelijke vraagstukken identificeren en aanpakken. We moeten ook luisteren naar de politiek, en ons afvragen waarom door de politiek of de maatschappij bepaalde vragen worden gesteld. Gaat het om een verheldering of antwoord op iets dat we nog niet weten? Gaat het om een legitimering of validering van een mening? Of wil de politiek een waarschuwing afgeven voor bijvoorbeeld een falend beleid? Naar mijn idee zijn al deze redenen legitiem voor wetenschappelijk onderzoek. Ook een wetenschapper is in zekere zin een politicus (32): door een dialoog met politiek en maatschappij -dus meer vraag gestuurde wetenschap- kunnen we de relevante zaken op de agenda krijgen.

\section{De leerstoel}

Daarmee ben ik terug bij mijn leerstoel (33). Want onderzoek is nodig. Onderzoek naar de oorzaken van risicogedrag en de cumulatie van factoren, theoretisch onderzoek om de interventies te onderbouwen, procesonderzoek om de interventies te laten lopen zoals ze bedoeld zijn, en effectonderzoek om te weten of onze maatregelen en interventies werken. Evidence based werken is van belang: hiermee verhogen we de kwaliteit en effectiviteit van zorg en preventie, voorkomen we fouten die we maken door het inzetten van niet effectieve beleidsmaatregelen of interventies, en werken we veel kosten-effectiever: we gooien dan immers geen geld weg aan interventies waarvan we niet weten of ze werken.

Mijn leerstoel is ingesteld door het IVO en wordt gesteund door de Mondriaan, instelling voor Geestelijke Gezondheidszorg in Zuid-Limburg. De leerstoel is gepositioneerd binnen de School CAPRHI en meer in het bijzonder binnen het programma Health communication and theory and practice in health promotion. Binnen het Maastrichts Universitair Medisch Centrum wordt op vele plaatsen aandacht gegeven aan verslaving en ik zal mij inzetten om dat onderzoek bij elkaar te brengen en verder te ontwikkelen. Mijn onderzoek zal ik uitvoeren in samenwerking met medewerkers van de Universiteit Maastricht, van het IVO en van de Mondriaan. 
Mijn leerstoel heeft als leeropdracht: zorg en preventie van risicogedrag en verslaving. Ik zie hierbij verslaving als een recidiverende psychische aandoening en niet als een "morele zwakte" van individuen. Verslaving is daarmee niet slechts de eigen verantwoordelijkheid van het individu, maar tevens een verantwoordelijkheid van de maatschappij. Ik doe met deze leerstoel mijn best om mijn bijdrage hieraan te leveren.

\section{Dankwoord}

Dames en heren, tot slot enkele woorden van dank. Allereerst dank ik de Stichting IVO voor het instellen van de Leerstoel Zorg en Preventie van risicogedrag en verslaving. Ik dank de Raad van Toezicht van het IVO en de Universiteit Maastricht voor het in mij gestelde vertrouwen. Ik hoop het waar te kunnen maken.

Er zijn een paar mensen die een bijzonder woord van dank verdienen. Ten eerste Nanne de Vries, bij mijn aantreden nog voorzitter van de vakgroep Health Promotion en Onno van Schayk, destijds directeur van de onderzoeksschool CAPHRI. Zij hebben zich ingezet om de leerstoel van Ronald Knibbe te behouden en hadden het vertrouwen in mij om mij als zijn opvolger aan te stellen. Door hen heb ik mij bijzonder welkom gevoeld bij CAPHRI en bij de vakgroep. Het is een hele eer dat ik nu, als ik in Maastricht ben, op Nanne's kamer mag bivakkeren. Nanne: ik hoop nog lang met je te kunnen samenwerken, en ik kom ook nog steeds een keer bij je eten. De Mondriaan dank ik voor hun steun aan het aio-onderzoek.

Ik heb in het dankwoord van mijn vorige oratie een aantal mensen bedankt die aan mijn wetenschappelijke carrière op bijzonder wijze hebben bijgedragen. Dat zijn Henk Garretsen, Karien Stronks en Johan Mackenbach. Ik ga mijn woorden niet allemaal herhalen, maar weet dat mijn dank nog steeds even groot is! Ook de dank aan mijn IVO collega's blijt onverminderd. Speciaal noem ik Miranda Audenaerdt: het blijft bijzonder dat wij al zo lang, zo goed en zo leuk kunnen samenwerken. Aan de Universiteit Maastricht heb ik weer nieuwe inspirerende collega's ontmoet. Zoveel leuke en vooral betrokken mensen om mij heen maken dat ik dit werk met veel plezier doe.

Ik begon in 1982 in Maastricht als student gezondheidswetenschappen. Ik vind het erg leuk weer te mogen werken op de plek waar mijn wetenschappelijke opleiding begon. Zo zagen we er toen uit (34). Uit die tijd stamt ook mijn kennismaking met 
Ronald Knibbe, toen docent bij de capaciteitsgroep Medische Sociologie. Ronald: dank voor je onderwijs van toen, en dank voor de vele jaren leuke samenwerking daarna. Je was mijn theoretisch geweten. Mijn vrienden uit die tijd, de Maastrichtse kliek; jullie zijn nog steeds mijn beste vrienden, en dat is heel bijzonder. (35) Mijn ouders Jan van de Mheen en Betsy van de Mheen-Pijpers, gaven me de kansen en de vrijheid om te doen wat ik graag wilde. Ik mis vandaag mijn vader, die er niet meer is. Hij zou trots op mij zijn.

Joost, dank dat je er bent. Ik praat altijd al teveel, dit zegt denk ik genoeg. Mijn laatste woorden zijn voor Fien en Rosa. Fien, dank voor je ongebreidelde optimisme, bij jou is het glas altijd vol: jij hebt geen kraan meer nodig. Rosa, ik heb bewondering voor je focus: je spreekbeurt voor over drie weken heb jij al af. dat kon ik van dit verhaal niet zeggen.

Dan sluit ik af met een laatste filmpje. (36)

Ik heb gezegd. 


\section{Referenties}

1. Smit AB (2007) Hersenen op sterk water. Lezing FADO. Amsterdam: Vrije Universiteit.

2. Hammink A, M Altenburg, CTM Schrijvers (2012) De Sociale gevolgen van verslaving. Een state of the art studie naar verstoring van sociale relaties, schooluitval, dakloosheid, schulden en huiselijk geweld als gevolg van alcohol- of drugsverslaving. IVO Reeks 71. Rotterdam: IVO

3. Van Rooij AJ, GJ Meerkerk (2012) Gameadviesopmaat.nl: Bezoek in de eerste maanden [Personal game advice website: the statistics]. Rotterdam: IVO. Retrieved from http://bit.ly/YCzfPZ

4. Gunster B. Omdenken (2010) Utrecht: A.W. Bruna Uitgevers B.V.

5. Van Rooij AJ, TM Schoenmakers, D van de Mheen (2011) Factsheet Monitor Internet en Jongeren 2006-2010. Nederlandse jongeren op internet: applicaties, (overmatig) gebruik, en de relatie met middelengebruik. Rotterdam: IVO

6. Wisselink J, IVZ, persoonlijke mededeling

7. Van Rooij AJ, TM Schoenmakers, GJ Meerkerk, D van de Mheen (2008) Factsheet Monitor Internet en Jongeren. Videogames en Nederlandse jongeren [Monitor Internet and Youth. Video games and Dutch Youth]. Rotterdam: IVO

8. Van Rooij AJ, TM Schoenmakers (2013) Factsheet Monitor Internet en Jongeren 2010-2012. Het (mobiel) gebruik van sociale media en games door Jongeren. Rotterdam: IVO

9. Van Duin L, TM Schoenmakers, L Veldhuis, M Janikian (2013) Verslag over de Nederlandse jongeren binnen een Europees onderzoek naar risicovol en verslavend internetgebruik. Rotterdam: IVO

10. Trimbos-instituut/WODC (2013) Nationale Drug Monitor Jaarbericht 2012. Utrecht: Trimbosinstituut/ Den Haag: WODC

11. Van Rooij AJ, TM Schoenmakers, D van de Mheen (2011) Nationaal Prevalentie Onderzoek Middelengebruik 2009: De kerncijfers. Rotterdam :IVO

12. Bieleman B, Intraval, persoonlijke mededeling

13. Bieleman B, S Biesma, A Kruize, C Zimmerman, M Boendermaker, R Nijkamp, T Bak (2011) Gokken in kaart Tweede meting aard en omvang kansspelen in Nederland. WODC, ministerie van Veiligheid en Justitie. Groningen-Rotterdam: Intraval

14. Meerkerk GJ, DV van den Ende, M Altenburg, TM Schoenmakers (2011) De opwinding voorbij Aard, ernst en omvang van gebruik en problematisch gebruik van online pornografie in Nederland (pp. 1-66). Rotterdam: IVO, Rotterdam

15. http://mijnladis.sivz.nl/ladisnl.html

16. Fettes DL, GA Aarons, AE Green (2013) Higher rates of Adolescent Substance Use in Child Welfare Versus Community Populations in the United States. J Stud Alcohol Drugs;74:825834

17. Snoek A, EG Wits, JC van der Stel, H van de Mheen (2010) Kwetsbare groepen. Kwetsbare groepen jeugdigen en (problematisch) middelengebruik: visie en interventiematrix. Amersfoort: Resultaten Scoren

18. Hermanns J (2009) Het opvoeden verleerd. Amsterdam: Vossiuspers UvA

19. Rutter M (2008) Understanding and testing risk mechanisms for mental disorders. Journal of Child Psychology and Psychiatry

20. Evans G (2003) A multimethodological analysis of cumulative risk and allostatic load among rural children. Developmental Psychology, 39 (5), 924-933

21. Evans G, K English (2002) The environment of poverty: multiple stressor exposure, psychophysiological stress and socioemotional adjustment. Child Development, 73 (4), 1238-1248

22. Cuijpers $P$ (2009) Preventie. in: Franken I, Brink W van den (red.). Handboek Verslaving $p$. 231-244, Utrecht: De Tijdstroom

23. Hasselt van $\mathrm{H}$ (red.) (2010) Preventie van schadelijk alcoholgebruik en drugsgebruik onder jongeren (2010). Utrecht: Trimbos-instituut

24. Schelleman-Offermans K (2012) Growing up getting drunk. PhD Thesis. Maastricht: Maastricht University

25. Verdonk-Kleinjan WMI, RA Knibbe, B Bieleman, HN de Groot, H de Vries (2008) The tobacco sales ban and tobacco purchases by adolescents: a general population study in The Netherlands. Eur J Public Health 18 (5): 498-503

26. Oudejans S, M Spits (2013) Investeren in Verslavingspreventie. Amersfoort: Resultaten Scoren 
27. Maat MJ, IM Koning, J Lammers (2010) Alcohol preventie bij jongeren: ouders en school maken het verschil. TSG;88: 418-421

28. Van Laar M, M van Ooyen-Houben (2009) Evaluatie van het Nederland Drugsbeleid. Utrecht: Trimbis-instituut/Den Haag: WODC

29. Tweede Kamer. Beleidsnotitie drugsbeleid (2011) T.K. 24077-1259

30. Snoek A, EG Wits, H van de Mheen (2010) Vroegsignalering. Richtlijn vroegsignalering middelengebruik of - afhankelijkheid bij jongeren. Amersfoort, Resultaten Scoren

31. Couwenbergh C, E Wits (2013) Samenwerken om bij middelengebruik tijdig te signaleren, door te verwijzen en te behandelen. Voorbeelden van verslavingspreventie en -zorg voor kwetsbare jongeren in de verslavingssector. Rotterdam: IVO

32. Gemeente Rotterdam (2010) Aanvalsplan Drugs \& Alcohol op ROC's. Rotterdam: GGD Rotterdam Rijnmond

33. Braam R, H Verbraeck, F Trautman (2004) RAR Handboek Problematisch Middelengebruik. Rapid Assessment and Response methode voor doelgroepen met problematisch middelengebruik. Utrecht: CVO/Trimbos-instituut

34. Mackenbach JP (red.) (2011) Successen van preventie 1970-2010. Rotterdam: ErasmusMc

35. Unilever (2011) Inspiring sustainable living. Experts insights into consumer behaviour \& Unilever's Five levers for Change. London: Unilever PLC

36. Rijksoverheid (2013) Alles is gezondheid... Het nationaal Programma preventie 2014-1016. Den Haag: Rijksoverheid

37. Van Ewijk C, A van der Horst, P Bessling (2013) Gezondheid loont. Tussen keuze en solidariteit. Toekomst voor de zorg. Den Haag: Centraal Plan Bureau

38. Baaijens H, T Plochg (2013) Essay. De zorgfuik kan worden voorkomen. Dat lukt alleen als we de uitgangspunten van het zorgstelsel herzien Financieel Dagblad, 06-04-2013

39. Van den Berg M (red.), NSM Post, HH Hamberg-van Reenen, CA Baan, CG Schoemaker (red.) (2013) Preventie in de zorg. Themarapport Volksgezondheid Toekomst Verkenning 2014. Bilthoven: RIVM

40. Price Waterhouse Coopers (2010) Prevention pays for everyone. Oegstgeest: Prevent conference

41. NPHF federatie voor gezondheid (2012) Open brief aan minister Schippers: Gezondheidsdenken houdt zorg betaalbaar. Utrecht: NPHF

42. Expertcommissie Lijstensystematiek Opiumwet (2011) Drugs in lijsten. Den Haag: Expertcommissie Lijstensystematiek Opiumwet

43. Van de Mheen D (2008) Het doel heiligt de middelen? Rotterdam: Erasmus MC 